\title{
Construction of the Blended Teaching Model of Ideological and Political Course in Colleges and Universities
}

\author{
Pei Peng ${ }^{1}$ \\ ${ }^{1}$ School of Marxism, Jianghan University, Wuhan, Hubei 430056, China \\ Corresponding author.Email: 1664798059@qq.com
}

\begin{abstract}
The blended teaching model integrates online teaching with traditional entity classroom.It effectively combines the positive factors of online teaching and entity classroom to realize complementary advantages.It can effectively promote students' in-depth learning and the development of high-quality teaching resources,and improve the teaching effect and quality.The construction of the blended teaching model of Ideological and political course in universities includes online classroom and offline classroom.
\end{abstract}

Keywords: Ideological and political course, blended teaching model, online teaching, offline teaching.

\section{INTRODUCTION}

With the rapid development of information technology and the deepening of teaching reform in higher education, the blended teaching mode has gradually become the focus of teaching reform in Colleges and universities. The blended teaching mode effectively integrates online teaching with traditional entity classroom. It effectively combines the positive factors of online teaching and entity classroom to realize complementary advantages. It can effectively promote students' in-depth learning and the development of highquality teaching resources, and improve the teaching effect and quality.[1] The ideological and political course in Colleges and universities is the main position for ideological and political education for contemporary college students. In recent years, it has also kept up with the pace of the times and constantly innovated the teaching mode. Online and offline blended teaching has been gradually promoted in Ideological and political courses in Colleges and universities, and initial results have been achieved.[2]

\section{THE BLENDED TEACHING MODEL AND ITS CHARACTERISTICS}

The blended teaching mode mainly refers to the deep integration of network teaching and traditional teaching with the help of digital information network technology. According to the different teaching content and the learning needs of student groups, the blended teaching mode implements the division of teaching links and teaching functions, so that the teaching can be carried out simultaneously in the "offline" and "online", so as to expand the teaching function and improve the teaching effect. The blended teaching mode is not a simple superposition of traditional teaching and online teaching, but the combination and supplement of online learning and traditional classroom teaching. It can not only play the leading role of teachers, but also reflect the subjectivity of students, so as to achieve better teaching effect.

Professor He Kekang of Beijing Normal University was the first to formally advocate the blended teaching model in China.He believes that the blended teaching mode combines the advantages of traditional teaching methods with the advantages of network teaching. The blended teaching model not only gives play to the leading role of teachers in guiding, enlightening and monitoring the teaching process, but also fully reflects the students' initiative, enthusiasm and creativity as the main body of the learning process.[3]

Different from traditional teaching, the blended teaching has the characteristics of flexibility, openness and interactivity. First, the blended teaching has greater flexibility to realize the combination of systematic learning and scattered learning. Secondly, the blended teaching has an open nature, which provides more possibilities and convenience for students' independent 
learning through the online teaching platform. Finally, the blended teaching is interactive, which enhances the communication and interaction between teachers and students in the teaching process, and stimulates the students' sense of learning participation and gain.[4]

\section{THE DESIGN IDEA OF ONLINE AND OFFLINE BLENDED TEACHING}

The overall design idea of online and offline blended teaching is to use the online classroom and entity classroom platforms to promote the deep integration of online teaching and offline teaching, and realize the complementary advantages of online teaching and entity classroom.Specifically, it is to use information technology to embed high-quality resources into the curriculum architecture of the network teaching platform used by the curriculum.In the teaching process, online and offline blended teaching focuses on entity classroom teaching, supplemented by online guidance through the network. It combines online and offline teaching to give full play to the leading role of teachers and the dominant position of students. It is helpful for students to play their main role under the guidance and promotion of teachers. Using a variety of teaching methods to guide students to carry out online selflearning before class, inquiry in class and extended learning after class, online and offline blended teaching can effectively help students absorb knowledge and improve their ability. In the collaborative interaction between teachers and students, it can promote the improvement of teachers' ability, and improve students' comprehensive quality, and finally complete the teaching objectives of the course.[5]

In the online and offline blended teaching mode, online courses and offline entity classroom support each other. On the one hand, online courses can make full use of network resources to provide high-quality teaching resources for learning in offline entity classes. Under the permission of copyright, the online teaching platform can introduce one or more courses in whole or in part as recommended resources for students to study independently. Online network teaching platform is not only a platform for teachers to guide, answer questions, monitor, assess and evaluate students' learning, thinking, discussion and exploration, but also a basic curriculum model integrating teaching and learning activities such as pre class - in class - after class, online - offline, in class - after class and so on. Through the network teaching platform, teachers can not only arrange learning, self-test, take exams, and observe students' learning dynamics, but also supervise students' learning activities, organize online examinations as important reference data for assessment and evaluation. On the other hand, in the online and offline blended teaching model, the face-to-face entity classroom provides a learning environment for teachers and students to communicate and interact each other. In the face-to-face entity classroom, teachers and students can effectively carry out various forms of interactive communication, such as thematic discussion and on-site $\mathrm{Q}$ and $\mathrm{A}$, then realize the mutual benefit of teaching and learning. Under the guidance and organization of teachers, students can carry out autonomous learning, cooperative learning, inquiry learning, thematic discussion, project research and other learning activities. ${ }^{[9]}$

\section{CONSTRUCTION OF ONLINE AND OFF LINE BLENDED CLASSROOM OF IDEOLOGICAL AND POLITICAL COURSE IN COLLEGES AND UNIVERSITIES}

The ideological and political course in Colleges and universities is the main position for ideological and political education for contemporary college students. College students in the new era grow up in the environment of socialist market economy and opening to the outside world. Their value orientations are diverse and complex, and they are vulnerable to the influence of various external ideologies and cultures. How to guide contemporary college students to correctly understand the development trend of the world and China needs to play the guiding and leading role of Ideological and political course. Therefore, the ideological and political course in Colleges and universities needs to innovate the teaching mode, stimulate students' interest in learning, really make college students firm their faith and effectively improve the teaching effect of Ideological and political course in Colleges and universities.[6]

According to the characteristics and design ideas of blended teaching, combined with the teaching requirements of Ideological and political courses in Colleges and universities, the construction of online and offline blended classroom includes two levels: online classroom and offline classroom.

\subsection{Construction of online classroom}

SPOC (small private online course) course platform should be selected as the online classroom mode of Ideological and political course in Colleges and universities. Because of its limited registration scale, SPOC can improve students' learning participation and interaction. It also enables teachers to observe learning status in real time, understand learning dynamics, interaction between teachers and students in online discussion areas, sort out typical problems in advance, then discuss them in offline class, or form the subject source of practical teaching, which is conducive to the realization of diversified and three-dimensional teaching.[7]

The construction of online classroom mainly includes four parts: 
First, the teaching of main knowledge points. It is mainly presented on the SPOC course platform in the form of teaching video, which is generally recorded by the instructor of the course and embedded in SPOC after being produced by a professional production company. Teaching video should closely follow the teaching materials and decompose the teaching content into independent knowledge points.

Second, homework and exercises. The assignments on the online course platform can be roughly divided into two categories. One is interspersed in the teaching video. According to the function of the network platform, relevant questions can be set at a fixed time point of the teaching video. Students can continue to watch after they answer correctly. This kind of homework is not difficult. Another kind of homework can be set after the teaching video and reading materials, or it can be published separately by the teacher at a fixed time point. The difficulty of this kind of homework has been improved to a certain extent, which not only examines the students' mastery of basic teaching knowledge, but also examines the students' ability to transfer and apply knowledge.

Third, interactive discussion area. Interactive discussion area is a space for students and teachers, students and students to discuss and exchange views with each other. On the SPOC course platform, teachers can appropriately set theme discussion questions according to the teaching progress, and students can discuss and post. After teachers review, they can answer questions and solve doubts for students online, and understand students' learning in time. Students can see their learning progress and homework completion in the interactive discussion area.[8]

Fourth, expand resources. One of the important advantages of online classroom is its large capacity, which can introduce a large number of extended materials on the course platform, such as relevant video materials (film and television dramas, documentaries, etc.), audio materials, relevant historical materials, etc. The purpose of this kind of materials is to help students better understand the relevant teaching contents. Teachers' teaching plans and courseware can also be introduced into the course platform, and the latest academic research results of relevant issues can also be uploaded for the use of students with good foundation and interested in in in-depth learning.

The online classroom of Ideological and political course in Colleges and universities constructed through the above plates can basically complete the effective transmission of course knowledge.

\subsection{Construction of offline classroom}

Offline face-to-face classroom is the basis and core of creating online and offline blended courses of
Ideological and political courses in Colleges and universities. Facing the huge amount of information in the information age, it is very important for college students to correctly treat and distinguish and form a correct world outlook and outlook on life. Therefore, face-to-face teaching, communication and discussion between teachers and students must be carried out with the help of offline face-to-face classes.[9]

First, we can carry out special teaching on the key and difficult problems of the course. The online teaching video contains the basic knowledge of the course content. The key and difficult problems of the course content must be taught in the face-to-face classroom in order for students to really master them. Key and difficult problems require teachers to guide students to correctly understand them through dialectical analysis of different views, classroom questioning and discussion. Special lectures can expand students' academic vision, improve students' judgment and enhance students' ability to analyze problems with Marxist positions, viewpoints and methods.

Secondly, classroom discussion topics can be set according to the interests and curriculum contents of college students. College students in the new era are full of passion and desire to explore. It is easy to be interested in the experience of their peers, so they can set relevant discussion topics. Teachers arrange discussion topics on the online course platform in advance, push relevant materials such as documentaries and relevant academic articles, and remind students of relevant precautions. Students form their own views after consulting relevant materials. Discuss in groups in offline face-to-face classes, and teachers will guide and summarize appropriately. In the process of consulting materials, thinking and discussion, students have completed the transformation from passive acceptance to active learning. The topic of class discussion can also be set according to the specific content of the chapter. In the process of thinking and discussion, students not only expand their academic vision and improve their judgment, but also enhance their ability to analyze problems with Marxist positions, viewpoints and methods.[10]

In addition, it can also be connected with the knowledge points of online teaching video, and carry out teaching activities such as speech, interaction and discussion in offline classroom to stimulate students' learning interest and enthusiasm.

\section{CONCLUSION}

In the era of highly developed information technology, higher education is also facing profound changes. The blended teaching model integrates online teaching with traditional entity classroom. It effectively combines the positive factors of online teaching and 
entity classroom to realize complementary advantages. It can effectively promote students' in-depth learning and the development of high-quality teaching resources, and improve the teaching effect and quality, and promotes the in-depth promotion of higher education teaching reform.

As the main position of Ideological and political education for contemporary college students, the ideological and political course in Colleges and universities is also constantly innovating the teaching mode. The ideological and political course in Colleges and universities has stimulated students' interest in learning through the development of blended teaching combining online classroom and offline classroom. In the process of blended teaching, under the guidance of teachers, college students gradually establish correct values, firm faith, consciously integrate their personal ideal pursuit into the cause of the country and the nation, and establish the faith and confidence to fight for the lofty ideal of communism and the common ideal of socialism with Chinese characteristics, so as to achieve the teaching goal of Ideological and political course in Colleges and universities. At the same time, the development of blended teaching of Ideological and political course in Colleges and universities has also comprehensively improved teachers' teaching ability and students' learning ability.[11]

\section{ACKNOWLEDGMENTS}

This work was supported by a grant from Department of Education of Hubei Province: Exploration and practice of blended teaching of Ideological and political course in colleges and universities in the new era(20Z021).

\section{REFERENCES}

[1] Y.H.Luo, Construction and practice of blended teaching model in Colleges and Universities, Higher Education Exploration, 2019(12): pp.4855.

[2] J.Li, Zh.J. Zhang, Research on the blended Teaching Model of Ideological and Political Theory Course in Higher Education.Review of Higher Education,2020(05 ): pp.68-76.

[3] K.K.He,New development of educational technology theory from blending learning (I) eEducation Research, 2004 (03): 1-6.

[4] SH.Tan, Construction of "blended teaching" mode in Colleges and universities pointing to deep learning, China Higher Education. 2019 (06);pp. 51-53.
[5] SH.SH.Shan, The construction and practical exploration of student-centered blended teaching model,Science \& Technology Vision,2021( 13 ): pp.19-20.

[6] Y.M.Gu, Research on the integration of traditional advantages of Ideological and political theory courses with information technology in the new era, Leading Journal of Ideological and Theoretical Education, 2018 (09): pp.75-78.

[7] L.X.Yao, G.W. Zhou, Design and teaching effect analysis of SPOC Blended teaching mode in Colleges and universities.J. Academic Journal of education., 2018(12): 92-100.

[8] SH.Q.Wang, L.H. Zeng, Exploration on the blended teaching mode of "MOOC + SPOC + flipped classroom" of Ideological and Political Course,Ideological \& Theoretical Education,2019(06): pp.68-73.

[9] X.P.Ling, R.J.Zhang, Y.F.Yan, Research on online and offline blended teaching mode of Ideological and political courses in Colleges and universities. The Party Building and Ideological Education in Schools, 2020 (10): pp.46-49.

[10] R.ZH.Zhang , Y.Liang, Thinking about promoting the mixed teaching of Ideological and political theory courses,Ideological \& Theoretical Education,2019(06): pp.65-69.

[11] B.Zhang, SH.CH.Zhang, Three Synergy of the Integrated Teaching of Ideological and Political Courses in Colleges and Universities, Ideological and Political Education Research,2020(06): pp.98101. 